\title{
MOLECULAR AND MORPHOLOGICAL CHARACTERIZATION OF MAIZE GENOTYPES FOR OPAQUE 2 GENE AND YIELD CONTRIBUTING TRAITS
}

\author{
Razia Sultana ${ }^{1,2,3^{*}}$
}

\author{
${ }^{1}$ Department of Plant Breeding and Genetics, University of Agriculture, Faisalabad \\ ${ }^{2}$ Agricultural Biotechnology Research Institute, Ayub Agriculture Research Institute, Faisalabad \\ 3International Maize and Wheat Improvement Centre (CIMMYT), Pakistan \\ *Corresponding author Email: raziasultana_uaf@yahoo.com
}

This is an open access article distributed under the Creative Commons Attribution License, which permits unrestricted use, distribution, and reproduction in any medium, provided the original work is properly cited.

\section{ARTICLE DETAILS}

\section{Article History:}

Received 23 November 2018 Accepted 26 December 2018 Available online 12 January 2019

\section{ABSTRACT}

\begin{abstract}
Maize (Zea maiz) is an important cereal crop grown on $480 \mathrm{~N}$ to $580 \mathrm{~N}$ with annual rain fall $250 \mathrm{~mm}$ to $5000 \mathrm{~mm}$ per year and having chromosome number $2 n=2 x=20$. Like all cereal crops maize is also deficient in two essential amino acids tryptophan and lysine in maize grain, but some maize mutant identified in USA have higher tryptophan and lysine contents due to presence of opaque 2 gene. In the present study 50 maize inbred lines and 30 QPM hybrids were characterized for morphological and yield contributing traits. 50 inbred lines were screened for the presence of opaque 2 gene. Molecular characterization showed that all 50 genotypes were non QPM as two primes phi 57 and phi 112 confirmed by amplifying $169 \mathrm{bp}$ in QPM and 161 in inbred lines whereas phi 112 amplified null fragments in QPM and $150 \mathrm{bp}$ in all inbred lines. Analysis of variance, principal component and cluster analysis showed presence of wider diversity in maize inbred lines and QPM hybrids. There were highly significant differences present in inbred lines for all the parameters studied where as QPM hybrids were found to be non-significant for ear aspect, plant aspect, days to $50 \%$ silking, days to $50 \%$ tasseling and anthesis to silking interval. Correlation among different traits were also determined and it was found that plant height and ear height had highly significant positive correlation $\left(0.483^{* *}\right.$ and $0.423^{* *}$ respectively) with yield per plant, ear diameter and number of grains per row had significant positive correlation $\left(0.303^{*}\right.$ and $0.556^{*}$ respectively) with yield per plant in inbred lines whereas in QPM hybrids field weight was positively correlated $\left(0.38^{*}\right)$ with grain texture and negatively correlated $\left(-0.778^{* *}\right)$ with plant aspect and ear aspect.
\end{abstract}

\section{KEYWORDS}

Zea mays, Opaque-2 gene, PCA analysis, Correlation, Cluster analysis.

\section{INTRODUCTION}

According to FAO 794.6 million people are under nourished in the world and prevalence rate of malnourishment is about 10.9 percent [1]. Out of 794.6 million people in the world 779.9 million malnourished people belong to developing countries with 511.7 million only in Asia including Pakistan and 14.7 million people are from developed countries. Therefore, a lot of work has to be done in the developing countries for obtaining objectives of food security. For overcoming the problem of malnourishment food should be available, accessible and of sufficient quantity and quality. In world major source of food is from cereal crops including wheat, rice, maize, barley and millet etc.

There are about dozen of cereal crops grown for food and feed but most important are wheat, rice and maize covering the $94 \%$ of world cereal production [2]. Cereals can provide approximately $50 \%$ protein and have potential to meet protein requirement up to $70 \%$ [3]. This $50 \%$ protein is not the balance protein as mostly all cereal crops are deficient in essential amino acids like lysine and tryptophan. Range of lysine and tryptophan in cereal is from 1.5 to $2 \%$ and 0.25 to $0.5 \%$ respectively whereas requirement for the optimal human diet is $5 \%$ lysine and $1.1 \%$ tryptophan $[3,4]$. Deficiency of lysine and tryptophan causes kwashicore disease in children which is characterized by growth failure, fatty liver, adema and irratibility [5].

Maize (zea mays L.) was one of the first plants cultivated by farmer between 7000 and 10,000 having centre of origin Mexico. It is a crop of subtopical and temperate region and a C4 plant [2]. Maize is the third most important cereal crop in Pakistan and it is consumed as a staple food in many countries of the world like USA. Maize is not only cultivated for the human food but also for the livestock feed that fulfills the requirements of protein, minerals and starch. In Pakistan maize is cultivated in two seasons autumn with $80 \%$ of cultivation and spring with $20 \%$ of cultivation $35 \%$ of total production is used as feed, $23 \%$ as food and $31 \%$ for other uses [6]. It contributes $2.2 \%$ value added in agriculture $0.4 \%$ to GDP. The area under maize cultivation is 1144 thousand hectares and production is about 4.920 million tonnes.

During 1960s and 1970s many maize mutants were identified having high level of lysine and tryptophan. These mutants were conferring the presence of mutant genes like opaque-2 (o2), floury-2 (fl2), opaque-7 (o7), opaque-6 (o6) and flouri-2 (fl2) causing higher level of lysine and tryptophan [5]. Opaque 2 mutation is a regulatory mutation that directly effects the transcription of zein mRNA by down regulating it [7-9]. Presence of this gene not directly involved in the synthesis of lysine or tryptophan, it has been observed that due to its presence proportion of zein protein is reduced and an increase non zein protein that is actually high in lysine and tryptophan and maintains the total protein of the grain at same level [5]. A group researcher found that tryptophan show significant negative correlation with zein protein [10]. Opaque 2 mutant gene can be easily manipulated during breeding program and its presence in homozygous form doubles the amount of lysine and tryptophan [11].

Opaque 2 mutation results in the soft endosperm due to pleotropic effects which causes undesirable phenotype leading to low yield, chalky kernel that renders the kernel susceptible to storage pest and ear rot. Interdisciplinary research team at International Maize and Wheat Improvement Centre (CIMMYT), Mexico converted the floury soft endosperm into hard endosperm by using conventional breeding methodologies that has same yield potential, resistant to insect pes,t same 
storage and utilization quality to superior normal maize lines. Opaque-2 maize which was developed at CIMMYT was agronomically acceptable and nutritionally improved and termed as "Quality Protein Maize" or QPM [5]. QPM has potential to meet $100 \%$ requirement of lysine and tryptophan by consuming $100 \mathrm{~g} /$ day for younger and $500 \mathrm{~g} /$ day for adults. In a metaanalysis of nine community base studies showed that there is $9 \%$ increase in growth rate in height and $12 \%$ increase in growth rate of weight [12]. Simple sequence repeats (SSR) are genomic reigon which consists of highly variable tandem repeats with two to six DNA nucleotides also known as microsatellite [13]. These SSRs are used as flanking primers for the amplification of desired gene using PCR [14]. The amplified products are separated electrophratically follow mandalian inheritance, behave as codominant genetic marker and are highly polymorphic [15]. Yield contributing traits like 100 grain weight, yield per plant, cob diameter, cob length etc plays important role in selecting maize genotypes for variety development and are essential for breeding program and should be taken into account either simultaneously or alone for selecting high yielding genotypes. For developing a commercial QPM hybrid there must be a procedure study on the characterization of genotypes for agronomic traits [16]. For evaluation of large number of genotypes in breeding program statistical tools like $\mathrm{D}^{2}$ and principle component analysis are used for checking the genetic potential and genetic divergence among genotypes. Keeping in view the above-mentioned facts, current study was conducted with the following objectives; to access variability among maize inbred lines for various agro-morphological traits and the presence of opaque 2 to access variability and performance of QPM hybrids in Pakistani climate.

\section{MATERIALS AND METHODS}

The proposed study was carried out to evaluate the presence of opaque 2 gene and genetic diversity between 50 maize genotypes. The said research consists of two analyses. The first analysis conducted for screening the 50 maize genotypes for opaque 2 gene at seedling stage using three SSR opaque 2 specific primers. Plant material consists of 50 maize genotypes that were taken from Pakistan Genetic Resource Institute (PGRI) and 12 QPM hybrids from CIMMYT. Genotypes were grown in the field of University of Agriculture, Faisalabad in Randomized Complete Block Design with two replications in $5^{\text {th }}$ of August.

\subsection{Molecular analysis}

Leaf sample was taken from the four weeks-old seedling and genomic DNA was isolated according to standard protocol of GMO testing lab of Agriculture Biotechnology Research Institute, Ayub Agriculture Research Institute, Faisalabad. The protocol was as follows: Leaf tissue was ground to fine powder in liquid nitrogen using pre chilled autoclaved pastlemortar. Approximately $1 \mathrm{~g}$ of ground material was transferred into $15 \mathrm{ml}$ falcon tube having $5 \mathrm{ml}$ pre heated CTAB buffer. The contents were shacked well and incubated at $65 \mathrm{oC}$ for 45 minutes. During incubation, tubes were inverted 2-3 times to mix the content. After incubation $5 \mathrm{ml}$ of chloroform isoamyl $(24: 1, \mathrm{v} / \mathrm{v})$ was added in the falcon tubes and inverted gently to mix the contents. Then the samples were centrifuged for 10 minutes at room temperature at 4000 revolution per minute (rpm). After $10 \mathrm{~min} .5 \mathrm{ml}$ supernatant was transferred into new falcon tubes of $15 \mathrm{ml}$. Then equal volume of chilled propanol was added to precipitate the DNA. For precipitation samples were centrifuged for 10 minutes at $4^{\circ} \mathrm{C}$ to take pellet. After centrifuged, the supernatant, the pellet was washed with 70 $\%$ ethanol. The pellet was kept in fume hood overnight. Next day, $500 \mu \mathrm{l}$ double distilled de-ionized water was added in falcon tubes to dissolve the pellet by shaking it with hands. When pellet dissolved the solution was shifted in eppendorfs $(1.5 \mathrm{ml})$ and $5 \mathrm{ul}$ RNAs was added. Then these tubes were shifted in incubator at $37^{\circ} \mathrm{C}$ for 1 hour. After dry heating add $500 \mu \mathrm{l}$ chloroform and isoamyl $(24: 1, v / v)$ was added and centrifuged the samples for 10 minutes at $13000 \mathrm{rpm}$ in micro centrifuge for phase separation. Then supernatant was taken and transferred into new eppondorf tubes. Then double volume of chilled propanol was added and centrifuged the samples at $4^{\circ} \mathrm{C}$ for 10 minutes. Washed final pelle with $70 \%$ chilled propanol, dried and dissolved in $200 \mu \mathrm{l}$ d3H2O. DNA quantification was done by using the spectrophotometer (Nano drop $2000)$ and working dilutions ( $15 \mathrm{ng} / \mathrm{ul}$ ) was made to perform PCR.

\subsubsection{SSR analysis}

SSR analysis was done using to o2 specific primers phi 57 and umc 1066 the co-dominated primers and phi 112, the dominated primers. Primers were bought from Gene link. Primer sequences, their annealing temperature and amplified products were as followed:

\begin{tabular}{|c|c|c|c|}
\hline Primers & Sequence & $\begin{array}{l}\text { Anealing } \\
\mathrm{T}\left({ }^{\circ} \mathrm{C}\right)\end{array}$ & $\begin{array}{l}\text { PCR } \\
\text { Product(bp) }\end{array}$ \\
\hline \multirow[b]{2}{*}{ phi057 } & F: 5'-CTCATCAGTGCCGTCGTCCAT-3' & 61.2 & \multirow[b]{2}{*}{153} \\
\hline & R: 5'-CAGTCGCAAGAAACCGTTGCC-3' & 61.6 & \\
\hline \multirow[b]{2}{*}{ umc1066: } & F: 5'-ATGGAGCACGTCATCTCAATGG-3' & 58.7 & \multirow[b]{2}{*}{143} \\
\hline & $\begin{array}{l}\text { R: 5'-AGCAGCAGCAACGTCTATGACACT- } \\
3^{\prime}\end{array}$ & 62 & \\
\hline \multirow[b]{2}{*}{ phi112: } & F: 5'-TGCCCTGCAGGTTCACATTGAGT3' & 62.9 & \multirow[b]{2}{*}{151} \\
\hline & R: 5'-AGGAGTACGCTTGGATGCTCTTC- 3' & 60.7 & \\
\hline
\end{tabular}

Polymerase reaction was performed in 20 ul reaction volume. Amplification was performed in thermo cycler. The phi 112 amplified fragments were resolved by agarose gel electrophoresis on $2 \%$ agarose prepared in $0.5 \times$ TBE buffer. Hundred bp ladder was used and gel was run for three hours at 100 volts. After staining with ethidium bromide $(0.5$ $\mathrm{ug} / \mathrm{ul}$ ) gel was visualized and documented on gel documentation system. For phi 57, $6 \%$ ployacryalmide gel was prepared in $0.5 x$ TBE buffer and over run with 50 bp ladder for 40 mimutes. After staining with AgNo3 gel bands were visualized and documented on transluminator and gel documentation system respectively. SSR profile was scored as presence or absence of fragments in each sample.

\subsection{Morphological analysis}

For morphological analysis three plants from each replication were studied. Parameters that recorded at maturity for inbred lines were as follows: days to $50 \%$ silking, days to $50 \%$ tasseling, plant height $(\mathrm{cm})$, ear height $(\mathrm{cm})$, No. of ears per plants, Number of grains per ear, Number of grain per row, Ear diameter $(\mathrm{mm})$, Ear length $(\mathrm{cm}), 100$ seed weight $(\mathrm{g})$ Yield per plant (g), Anthesis to silking interval (ASI). Parameters that recorded at maturity for QPM hybrids were as follows; Days to $50 \%$ silking, Days to $50 \%$ tasseling, Plant height $(\mathrm{cm})$, Ear height $(\mathrm{cm})$, Lodging, Field weight, Grain moisture, Ear aspect, ear Texture, Rotten ears, Plant aspect. The mean values of accessions in each replication were used for the analysis of variance and each character was subjected to analysis of variance. Significance of difference among all characters tested as described [17]. In order to make grouping, means of all accessions were compared using Tukey's Honestly Significant Difference (HSD). Correlation analysis, PCA analysis and cluster analysis were estimated using software XL-STAT 2016 to group the genotypes into homogenous classes. Cluster analysis was used to evaluate the genotypes for their diversity $[18,19]$.

\section{RESULTS AND DISCUSSION}

Increasing rate of malnourishment due to shortage of quality foods leads to many efforts that are being made to overcome it through biofortification. Deficiency of quality protein which is characterized by the deficiency of essential amino acids is also a major type of malnourishment. From 1960s to onwards there are many milestone achievements in maize biofortification for quality protein after the discovery of high lysine and tryptophan mutant in maize, the opaque 2 mutant. Efforts are also being made in Pakistan for the evaluation of genotypes for opaque 2 gene and various agro-morpho traits that contribute towards higher yielding. For the development of new varities germplasm collection and evaluation are essential components of a breeding program.

\subsection{SSR analysis}

Three primers used for identifying the presence of opaque 2 gene in maize inbred line and 12 QPM hybrids were used as control. Out of three primers phi 112 and phi 57 gave positive results. Primer phi112 revealed amplification products in all 50 maize lines and a null allele in nine QPM hybrids out of 12 (Figure 1). Primer umc1066 showed no results in QPM hybrids therefore it was not used for further analysis. Primer phi 112 amplified a band size of approximately $150 \mathrm{bp}$ in all inbred lines and null amplification in QPM 11 which was used as control (Figure 2). Phi 57 
amplified a band size of approximately $169 \mathrm{bp}$ in all maize inbred lines (Figure 3 and Figure 4). Phi 57 revealed differences between normal maize and opaque 2 lines. The bands amplified by phi 57 were around $170 \mathrm{bp}$ in non lines that not contained opaque 2 gene whereas a band size of approximately $160 \mathrm{bp}$ in QPM lines. Studies showed that phi057 amplified a band size of $165 \mathrm{bp}$ for opaque 2 lines and of $159 \mathrm{bp}$ for non opaque 2 lines. Whereas in the studies of QPM lines gave a band size of about $170 \mathrm{bp}$ and normal lines a band of approximately $160 \mathrm{bp}$ [20]. This marker can be recommended for distinguishing between homozygous and heterozygous backcross progeny during the development of QPM hybrids. In present study phi 57 amplified fragments in 9 QPM hybrids and 50 inbred lines with band size ranged from 160 to 170 bp respectively. These QPM specific primers could be used for foreground marker assisted selection (MAS) to identify the gene of interest without extensive phenotypic selection.

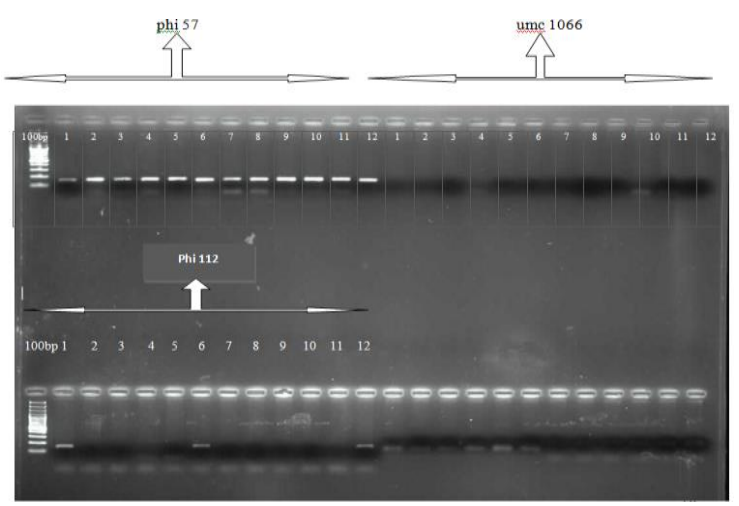

Figure 1: SSR profile of QPM hybrids for primers phi 57, umc 1066 and phi 112

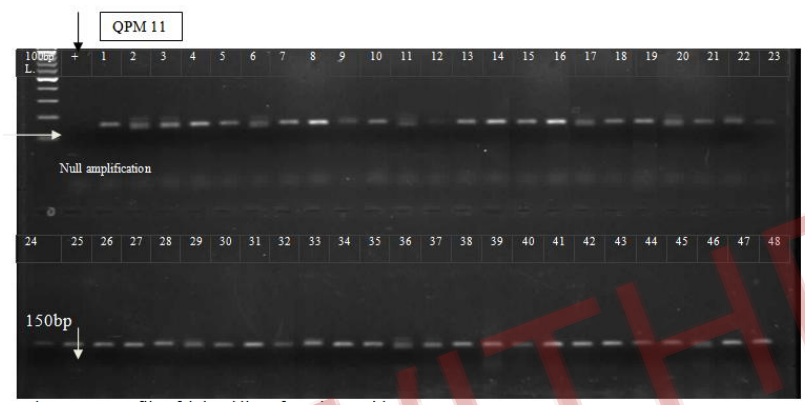

Figure 2: SSR profile of inbred lines for primers phi 112

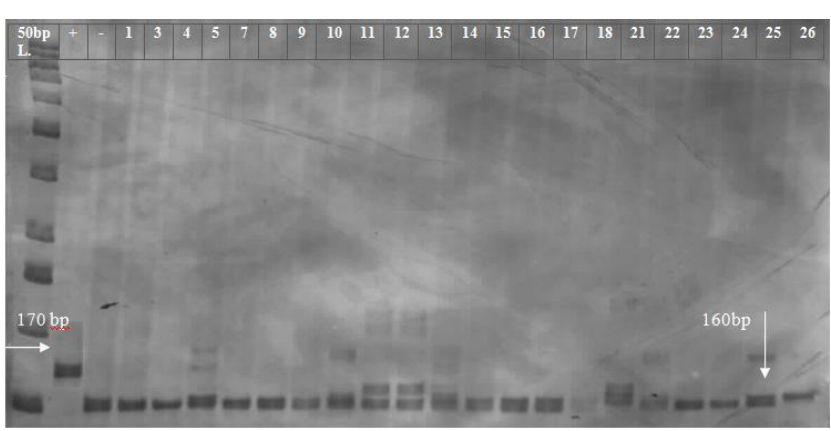

Figure 3: SSR profile of inbred lines primers phi 57

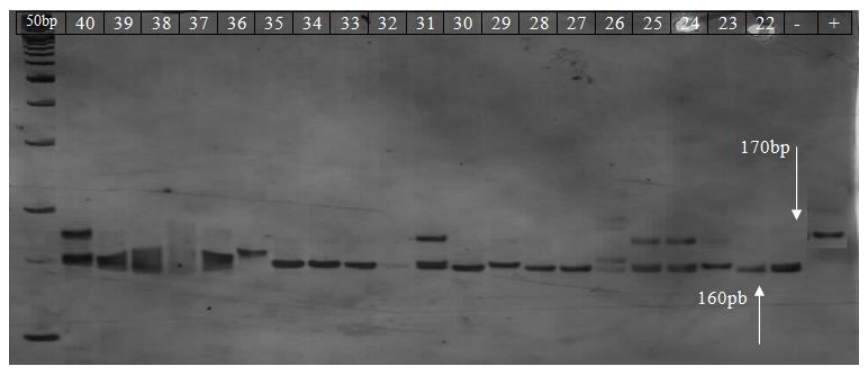

Figure 4: SSR profile of inbred lines primers phi 57

\subsection{Analysis of variance}

All the statistical analysis performed on various agro-morphological traits had revealed the presence of significant variation for all the traits of inbred lines (Table 1). The traits that were differ highly significantly were plant length, ear length, 50\% tasseling, 50\% silking, anthesis to silking interval, ear length, ear diameter, number of ears, number of rows per ear, number of grains per row, yield per plant and 100 grain weight. Ghimire also determined highly significant differences for these traits [21]. Analysis of variance of the data reflected high level of variation in QPM hubrids (Table 2) for the quantitative characters i.e. days to anthesis, days to silking, plant height, ear height, field weight and grain moisture. High variability for agronomic traits in this germplasm was also supported by findings of previous studies [22-24].

Table 1: ANOVA for agro-morphological traits of inbred lines

\begin{tabular}{|l|l|l|l|l|l|l|l|l|l|l|l|l|l|l|}
\hline S.O.V & D.F & PH & EH & $\mathbf{5 0} \%$ T & $\mathbf{5 0 \% S}$ & ASI & EL & ED & NOE & NORPE & NOGPR & NOGPE & 100 Gwt & YPP \\
\hline Blocks & 1 & 0.0002 & 71.85 & 5.76 & 6.76 & 25 & 1.77 & 45.79 & 0.04 & 0.87 & 34.81 & 12658.8 & 20.50 & 127.39 \\
\hline Lines & $49 * *$ & $11.87^{* *}$ & $609.0^{* *}$ & $109.0^{* *}$ & $76.55^{* *}$ & $35.2^{* *}$ & $11.87^{* *}$ & $59.53^{* *}$ & $0.1^{* *}$ & $7.84^{* *}$ & $111.59^{* *}$ & $22105^{* *}$ & $70.75^{* *}$ & $\begin{array}{l}1062.2 \\
* *\end{array}$ \\
\hline Error & 49 & 2.165 & 4.75 & 6.90 & 5.43 & 6.5 & 2.165 & 4.53 & 0.0195 & 0.427 & 1.13 & 562.7 & 1.07 & 6.58 \\
\hline
\end{tabular}

(NS= if $\mathrm{p}$ value $>0.05,{ }^{* *}=\mathrm{p}$ value $<0.01, *=\mathrm{p}$ value $>0.01$ or $<0.05$ ), Where $\mathrm{PH}=$ plant height, $\mathrm{EH}=$ ear height, $\mathrm{ED}=$ ear diameter, $\mathrm{EL}=$ ear length, $\mathrm{YPP}=$ yield per plant, $100 \mathrm{Gwt}=100$ grain weight, $\mathrm{NOE}=$ number of ears, NORPE = number of rows per ear, NOGPR = number of grains per row, $50 \% \mathrm{~T}=$ tasseling, $50 \% \mathrm{~S}=50 \%$ silking, $\mathrm{ASI}=$ anthesis to silking interval.

Table 2: ANOVA for qualitative and quantitative traits of hybrids

\begin{tabular}{|l|l|l|l|l|l|l|l|l|l|l|l|l|}
\hline S.O.V & D.F & $\mathbf{5 0 \% T}$ & $\mathbf{5 0 \% S}$ & PH & EH & LODG & FW & GM & EA & ET & RE & PA \\
\hline Blocks & 1 & 2.40 & 4.26 & 490.6 & 89.64 & 4.26 & 5.43 & 9.87 & 90.15 & 1.35 & 0.06667 & 1.66667 \\
\hline Hybrids & 29 & $10.16^{\text {N.S }}$ & $9.67^{\text {N.S }}$ & $556.7^{* *}$ & $234.64^{* *}$ & $17.48^{* *}$ & $1.745^{* *}$ & $15.77^{*}$ & $0.52^{\text {N.S }}$ & $0.26^{\text {N.S }}$ & $2.35^{* *}$ & $0.52^{\text {N.S }}$ \\
\hline Error & 29 & 13.4000 & 13.0943 & 51.894 & 39.549 & 2.3356 & 0.33723 & 6.0428 & 0.56379 & 0.35000 & 0.20460 & 0.45977 \\
\hline
\end{tabular}

(NS $=$ if $\mathrm{p}$ value $>0.05,{ }^{* *}=\mathrm{p}$ value $<0.01,{ }^{*}=\mathrm{p}$ value $>0.01$ or $<0.05$ ) Where $50 \% \mathrm{~T}=50 \%$ tasseling, $50 \% \mathrm{~S}=50 \%$ silking, $\mathrm{PH}=$ plant height, $\mathrm{EH}=$ ear height, $\mathrm{LODG}=$ srem lodging, $\mathrm{FW}=$ field weight, $\mathrm{GM}=$ grain moisture, $\mathrm{EA}$ = ear aspect, $\mathrm{T}=$ ear texture, $\mathrm{RE}=$ rotten ear, $\mathrm{PA}=$ plant aspect.

\subsection{Correlation analysis}

Correlation plays pivotal role in the selection of right traits for breeding purposes. The correlation between various traits is because of the presence of linked genes. Environment-gene interaction is considered the outcome of this association between any two correlated traits. Sometimes the role of environment for both the traits is direct and synchronized in the same direction, while in other cases it could be in opposite or different directions [25]. 
correlation of plant height and ear height like the results [26]. Although most authors found strong correlative relation between plant height and ear height [27-29]. Plant height also found to have significant correlation with yield per plant, same results were also determined but it was highly significant [26]. Some researchers also reported grain yield to be positively associated with plant height [27]. Plant height also positively and significantly associated with $50 \%$ silking, these results were in agreement [30]. Positive significant was also observed in ear diameter and plant height, ear diameter and yield per plant same results were also observed but these results were highly significant [30]. Numbers of grains per row had highly and positive correlation with anthesis to silking interval, these results were in contradicts [30]. Days to $50 \%$ tasseling had significant positive correlation with days to $50 \%$ silking likes the results their results were highly significant [26]. Simple correlation analysis showed that there was highly significant positive correlation of days to $50 \%$ silking and anthesis to silking interval same results were also found [30].

Table 3: Correlation matrix for hybrids

\begin{tabular}{|c|c|c|c|c|c|c|c|c|c|c|c|c|c|}
\hline Variables & PH & $\mathbf{E H}$ & $50 \% \mathrm{~T}$ & $50 \% \mathrm{~S}$ & ASI & EL & ED & NOE & NORPE & NOGPR & NOGPE & 100Gwt & YPP \\
\hline PH & 1 & & & & & & & & & & & & \\
\hline EH & $0.804 * *$ & 1 & & & & & & & & & & & \\
\hline $50 \% \mathrm{~T}$ & 0.194 & 0.101 & 1 & & & & & & & & & & \\
\hline $50 \% \mathrm{~S}$ & $0.306 *$ & 0.187 & $0.823 * *$ & 1 & & & & & & & & & \\
\hline EL & 0.254 & 0.216 & -0.088 & -0.138 & -0.113 & 1 & & & & & & & \\
\hline ED & $0.505 * *$ & $0.350 *$ & -0.092 & -0.053 & 0.043 & 0.301* & 1 & & & & & & \\
\hline NOE & 0.166 & 0.174 & 0.037 & 0.006 & -0.045 & -0.175 & -0.014 & 1 & & & & & \\
\hline NORPE & -0.058 & 0.053 & -0.116 & 0.048 & 0.256 & -0.129 & -0.019 & 0.108 & 1 & & & & \\
\hline NOGPR & 0.141 & 0.174 & 0.136 & -0.111 & $-0.395 *$ & -0.026 & -0.016 & -0.197 & -0.156 & 1 & & & \\
\hline 100Gwt & 0.250 & 0.265 & 0.039 & 0.054 & 0.037 & 0.219 & 0.211 & 0.278 & -0.058 & -0.112 & -0.125 & 1 & \\
\hline YPP & $0.483 * *$ & $0.423 * *$ & 0.032 & 0.002 & -0.044 & 0.106 & 0.303* & 0.060 & 0.048 & $0.556 * *$ & $0.565 * *$ & 0.214 & 1 \\
\hline
\end{tabular}

(NS $=$ if $\mathrm{p}$ value $>0.05,{ }^{* *}$ (values bold and red $)=\mathrm{p}$ value $<0.01, *$ (values bold) $=$ p value $>0.01$ or $<0.05$ ) Where $\mathrm{PH}=$ plant height, $\mathrm{EH}=$ ear height, $\mathrm{ED}=$ ear diameter, $\mathrm{EL}=$ ear length, $\mathrm{YPP}=$ yield per plant, $100 \mathrm{Gwt}=100$ grain weight, $\mathrm{NOE}=$ number of ears, $\mathrm{NORPE}=$ number of rows per ear, NOGPR = number of grains per row, $50 \% \mathrm{~T}=$ tasseling, $50 \% \mathrm{~S}=50 \%$ silking, ASI = anthesis to silking interval.

In case of QPM hybrids (Table 4) results are slightly different of the same parameters. Plant height in hybrids was also significantly and positively correlated with ear height like the results [26,31]. But plant height was found to be correlated negatively and significantly with $50 \%$ silking, same result was also determined [31]. Days to $50 \%$ tasseling had highly significant and strong positive correlation with days to $50 \%$ silking like the results [31]. Days to $50 \%$ tasseling correlated significantly and positively with grain moisture and lodging, a group researchers found that days to $50 \%$ tasseling correlated highly significantly and positively with grain moisture [31]. Likewise, in other study, they found grain moisture to be positively correlated with days to anthesis [32]. It was found that lodging negatively correlated with rotten ears. Field weight correlated negatively and highly significantly with plant aspect and ear aspect these results were also supported [33,34]. Field weight was also correlated significantly and positively with grain texture. Whereas grain texture had negative and significant correlation with plant aspect and ear aspect. Some researchers also determined positive correlation of morphological traits with grain yield $[29,35]$.

Table 4: Correlation matrix for hybrids

\begin{tabular}{|c|c|c|c|c|c|c|c|c|c|c|c|}
\hline Variables & $50 \% \mathrm{~T}$ & $50 \% S$ & PH & EH & LODG & FW & GM & EA & $T$ & $\mathbf{R E}$ & PA \\
\hline $50 \% \mathrm{~T}$ & 1 & & & & & & & & & & \\
\hline $50 \% S$ & $0.920^{* *}$ & 1 & & & & & & & & & \\
\hline PH & -0.184 & $-0.378^{*}$ & 1 & & & & & & & & \\
\hline EH & -0.021 & -0.08 & $0.493^{* *}$ & 1 & & & & & & & \\
\hline LODG & $0.448^{*}$ & 0.39 & 0.134 & 0.098 & 1 & & & & & & \\
\hline FW & 0.08 & 0.085 & 0.061 & 0.149 & 0.072 & 1 & & & & & \\
\hline GM & $0.431 *$ & $0.474^{* *}$ & -0.226 & -0.35 & 0.358 & -0.05 & 1 & & & & \\
\hline EA & -0.052 & -0.104 & -0.12 & -0.316 & -0.133 & $-0.788 * *$ & 0.251 & 1 & & & \\
\hline$T$ & -0.133 & -0.189 & 0.07 & -0.008 & -0.148 & $0.385^{*}$ & -0.143 & $-0.410 *$ & 1 & & \\
\hline $\mathbf{R E}$ & -0.413 & -0.317 & -0.173 & -0.099 & $-0.373 *$ & -0.152 & -0.22 & 0.161 & 0.051 & 1 & \\
\hline PA & -0.052 & -0.104 & -0.12 & -0.316 & -0.133 & $-0.788^{* *}$ & 0.251 & $1.000 *$ & $-0.410^{*}$ & 0.161 & 1 \\
\hline
\end{tabular}

(NS $=$ if $\mathrm{p}$ value $>0.05, * *$ (values bold and red $)=\mathrm{p}$ value $<0.01, *($ values bold) $=$ p value $>0.01$ or $<0.05$ ) Where $50 \% \mathrm{~T}=50 \%$ tasseling, $50 \% \mathrm{~S}=50$ $\%$ silking, $\mathrm{PH}=$ plant height, $\mathrm{EH}=$ ear height, $\mathrm{LODG}=$ srem lodging, $\mathrm{FW}=$ field weight, GM = grain moisture, $\mathrm{EA}=$ ear aspect, $\mathrm{T}=$ ear texture, $\mathrm{RE}=$ rotten ear, $\mathrm{PA}=$ plant aspect. 


\subsection{Principal component analysis}

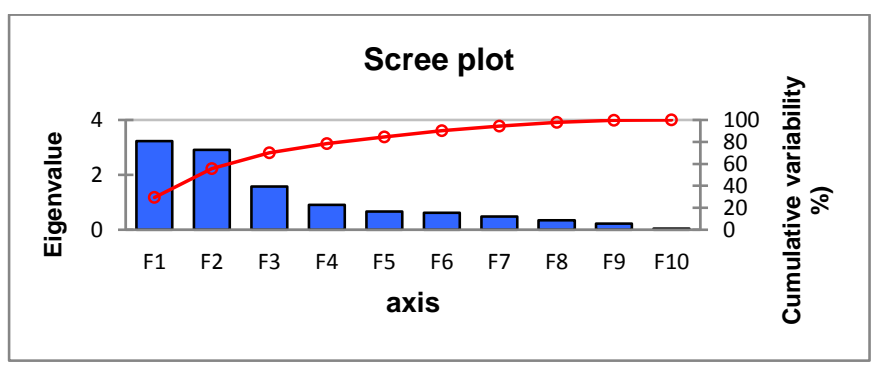

Figure 5: Eigen value and cumulative variability of principle components

The computed eigenvalues of twelve variables of 50 inbred lines were subjected to principal component analysis; their variability \% and cumulative explained variance are present in the following tables. Eigen values of twelve principle components had been shown in screw plot (Figure 5). Following proportion of variance criterion data revealed that out of eleven, five PCs describing more than one eigen values contributed $77.26 \%$ of variation and were selected for further explanation (Table 5). Principal component analysis resulted in the reduction of 12 original variables to five independent principal component variables. variables Plant height, ear height, 50\% silking, 50\% tasseling, ear diameter, ear length, yield per plant, 100 grain weight, number of rows per ear and number of grains per row were noted as characteristics of variability (Table 5).

Table 5: Cumulative variances and EigenValues for principal component (1-5)

\begin{tabular}{|l|l|l|l|l|l|}
\hline & PC1 & PC2 & PC3 & PC4 & PC5 \\
\hline Eigenvalue & 3.030 & 2.412 & 1.931 & 1.444 & 1.228 \\
\hline $\begin{array}{l}\text { Variability } \\
\text { (\%) }\end{array}$ & 23.304 & 18.551 & 14.851 & 11.109 & 9.448 \\
\hline $\begin{array}{l}\text { Cumulative } \\
\text { \% }\end{array}$ & 23.304 & 41.855 & 56.706 & 67.815 & 77.263 \\
\hline
\end{tabular}

Where PC1 = principle component $1, \mathrm{PC} 2=$ principle component $2, \mathrm{PC} 3=$ principle component $3, \mathrm{PC} 4=$ principle component $4, \mathrm{PC} 5=$ principle component 5.

According to first principal component most of variability was caused by plat height, ear height and yield per plant. These traits had important role in variation of PC1 cluster that accounts for $64.15 \%$. In PC1 maize genotypes were poor in ear length, 50\% tasseling, 50\% silking, number of rows per ear and number of grains per row. In the second principal component $50 \%$ silking, anthesis to silking interval, number of grains per row and number of grains per ear exhibited more variability and contribute $78.20 \%$ variation. In the third principal component traits that are contributing $75.02 \%$ variation are $50 \%$ tasseling and silking, ear length and ear diameter. Whereas genotypes of maize are poor in plant height, ear height and ear length. The fourth principal component can be considered as component of number of ears, number of rows per ear, 505 tasseling and anthesis to silking interval that had important role to produce $76.65 \%$ variation. Traits like plant height, ear height, 100 grain weight and 50\% silking were poor attributes in the genotypes of PC4. According to fifth principal component 100 grain weight, number of ears anthesis to silking interval accounts for $82.70 \%$ variation in the total variability of PC5 genotypes. Maize genotypes in the PC5 were poor in plant height, ear height, ear diameter, ear length and $50 \%$ silking (Table 6).

Table 6: Contribution of variables in total variability in (PC1-PC5) of inbred lines

\begin{tabular}{|l|l|l|l|l|l|}
\hline & PC1 & PC2 & PC3 & PC4 & PC5 \\
\hline PH & 28.473 & 0.006 & 0.153 & 0.098 & 0.361 \\
\hline EH & 23.783 & 0.103 & 0.436 & 0.776 & 0.605 \\
\hline ED & 11.025 & 3.729 & 5.299 & 4.869 & 0.866 \\
\hline EL & 3.391 & 6.768 & 2.544 & 29.072 & 0.851 \\
\hline YPP & 13.978 & 6.110 & 3.767 & 8.880 & 3.828 \\
\hline 100Gwt & 6.557 & 0.150 & 5.642 & 0.157 & 25.372 \\
\hline NOE & 1.138 & 0.755 & 5.055 & 31.450 & 25.421 \\
\hline NORPE & 0.006 & 2.664 & 7.860 & 17.040 & 18.633 \\
\hline
\end{tabular}

\begin{tabular}{|l|l|l|l|l|l|}
\hline NOGPR & 1.737 & 10.324 & 31.218 & 4.162 & 3.445 \\
\hline $\mathbf{5 0 \%}$ T & 2.968 & 15.370 & 23.549 & 0.962 & 6.874 \\
\hline $\mathbf{5 0 \% S}$ & 5.001 & 33.987 & 5.650 & 1.753 & 0.008 \\
\hline ASI & 1.943 & 20.035 & 8.828 & 0.781 & 13.737 \\
\hline
\end{tabular}

Where $\mathrm{PH}=$ plant height, $\mathrm{EH}=$ ear height, $\mathrm{ED}=$ ear diameter, $\mathrm{EL}=$ ear length, YPP = yield per plant, $100 \mathrm{Gwt}=100$ grain weight, $\mathrm{NOE}=$ number of ears, NORPE = number of rows per ear, NOGPR = number of grains per row, $50 \% \mathrm{~T}=$ tasseling, $50 \% \mathrm{~S}=50 \%$ silking, $\mathrm{ASI}=$ anthesis to silking interval, $\mathrm{PC} 1=$ principle component $1, \mathrm{PC} 2=$ principle component 2 , PC3 $=$ principle component $3, \mathrm{PC} 4=$ principle component $4, \mathrm{PC} 5=$ principle component 5 .

Biplot in the principal component represents variables that are super imposed on a plot as vectors where relative length of vectors represents the relative proportion of variability in each variable represented on biplot. If the angle between vectors of two trait is $<90^{\circ}$ both are positively correlated whereas if angle is $>90^{\circ}$ there is negative correlation and both vectors show no correlation if the angle is $90^{\circ}[36]$.

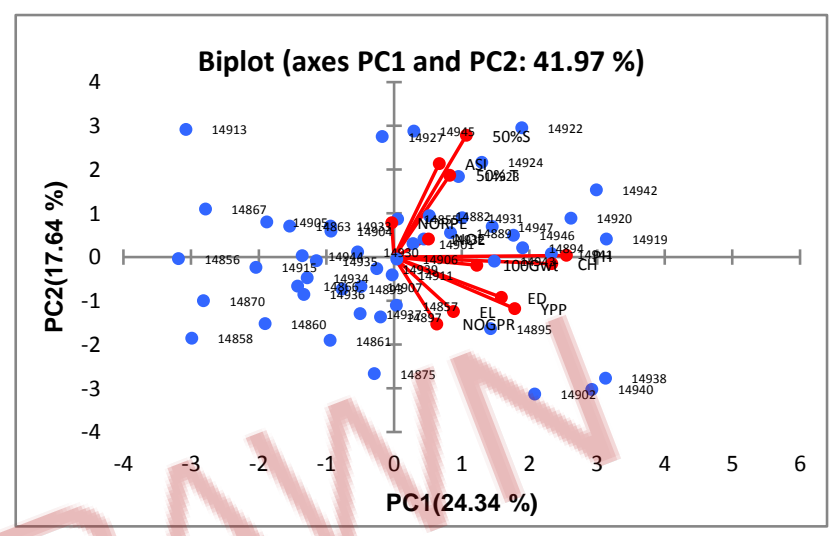

Figure 6: Two dimensional orientations of inbred lines for different traits on principle component biplot axis 1 and 2 . Where $50 \% \mathrm{~S}=$ days to $50 \%$ silking, $50 \% \mathrm{~T}=$ days to $50 \%$ tasseling, $\mathrm{ASI}=$ anthesis to silking interval, NORPE $=$ number of row per ear, $\mathrm{NOE}=$ number of ears per plant, $100 \mathrm{GW}$ $=100$ grain weight, $\mathrm{PH}=$ plant height, $\mathrm{CH}=$ cob height, $\mathrm{ED}=$ ear diameter, YPP = yield per plant and NOGPR = number of grain per row .

Contribution of PC1 towards variability was highest (24.33\%) followed by PC2, PC3, PC4 and PC5 which contributed 17.64\%, 13.86\%, 10.42\% and $10.09 \%$ variability respectively (Table 5). In PC1 and PC2 together 50\% silking, anthesis to silking interval, 50\% tasseling, plant height, ear height, ear diameter, ear length, yield per plant, 100 grain weight and number of grains per row's differences are well represented in the biplot but number of ears and numbers or rows per ear have minimum differences between PC1 and PC2 biplot (Figure 6). In summary, results of PCA analysis showed that all traits contribute differently in total variation. These variations are sources of germplasm improvement in the respective quantitative trait which contribute toward better agronomic performance and increase in yield potential. In biplot graph it was clearly indicated that their plant height and ear height had strong positive correlation among them.

A principal component scatter plot of maize germplasm depicts that genotypes which are similar in their performance with respect to twelve variables. Whereas genotypes which are father apart from one another are different. Genotypes which are more near to variable vectors are more important for that trait and vice versa. Therefore, scatter plot helped in the selection of genotypes for the yield contributing trait or for the trait that helped in better agronomic performance. In a given biplot it as clearly indicated that genotypes 14943, 14894, 14906, 14941 had higher 100 grain weight among 50 maize lines. Genotypes 14895 and 14938 had more yield per plant. Genotypes 14855, 14882, 14901 and 14952 had a greater number of rows per ear. For the selection of flowering traits 14927, 14945 14922, 14924 and 14923 genotypes are more important (Figure 6).

Genotype by Trait (GT) biplot is effective tool for revealing the interrelationships among the maize traits and it provides a tool for visual comparison among genotypes on the basis of multiple traits. Also, it can be used in independent culling based on multiple traits and in comparing selection strategies [37]. Genotype by Trait (GT) biplot provides a tool for visual comparison among genotypes on the basis of multiple traits. Also, it can be used in independent culling based on multiple traits and in comparing selection strategies, which is important for both cultivar evaluation and parent selection $[37,38]$. 
Based on this study of inbred lines of maize for example PC1 was best for plant height (PH) and ear height (EH) and yield per plant PC2 was best for days to $50 \%$ tasseling, days to $50 \%$ silking, anthesis to silking interval and for number of grains per row. PC3 was best for days to $50 \%$ tasseling and number of grains per row whereas PC4 and PC5 had characteristics features of numbers of ears, number of rows per ears and number of ears and 100 grain weight respectively. Overall in the 50 genotypes plant height $(\mathrm{PH})$ and ear height $(\mathrm{EH})$ and flowering traits are favorable characteristics for inbreds lines (Figure 6). Also, yield per plant (YPP), number of grains per row (NOGPR) and 100 grain weight (100Gwt) are major yield components and greatly affect grain yield should be considered in the maize breeding programs for improvement of these traits and yield.

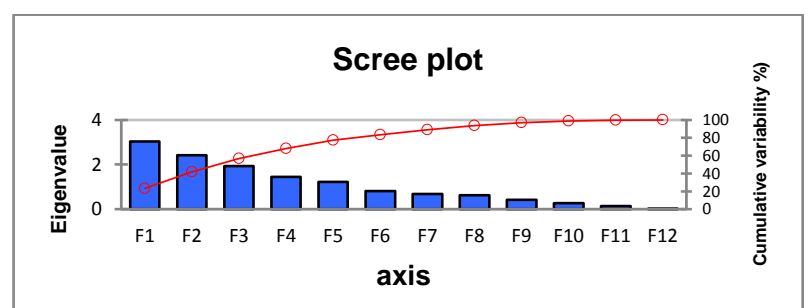

Figure 7: Eigen value and cumulative variability of principle components

The computed eigenvalues of eleven variables of 30 QPM hybrids were subjected to principal component analysis, their variability \% and cumulative explained variance are present in the following tables. Eigen values of eleven principle components had been shown in screw plot (Figure 7). Following proportion of variance criterion data revealed that out of eleven, three PCs describing more than one eigen values contributed $70.18 \%$ of variation and were selected for further explanation (Table 7). Principal component analysis resulted in the reduction of 11 original variables to five independent principal component variables.

Table 7: Cumulative variances and EigenValues for principal component (1-3)

\begin{tabular}{|l|l|l|l|}
\hline & PC1 & PC2 & PC3 \\
\hline Eigenvalue & 3.231 & 2.917 & 1.572 \\
\hline Variability (\%) & 29.374 & 26.516 & 14.290 \\
\hline Cumulative \% & 29.374 & 55.891 & 70.180 \\
\hline
\end{tabular}

Where PC1 = principal component $1, \mathrm{PC} 2$ = principal component $2, \mathrm{PC} 3=$ principal component 3.

According to first principal component most of variability was caused by plant aspect, ear aspect and field weight. These traits had important role in variation of PC1 cluster that accounts for $77.79 \%$. In PC1 maize genotypes were poor in ear length, $50 \%$ tasseling, 50\%silking and lodging. In the second principal component 50\% silking, 50\% tasseling and grain moisture exhibited more variability and contribute $70.84 \%$ variation. Second PA was poor for ear height, field weight, plant aspect and ear aspect. In the third principal component traits that are contributing $90.47 \%$ variation are plant height, ear height together contributing $62.54 \%$ variation and lodging, ear texture, and rotten ears that were contributing $27.93 \%$ significant variations (Table 8 ).

Table 8: Contribution of variables in total variability (PC1-PC3) of QPM hybrids

\begin{tabular}{|l|l|l|l|}
\hline & PC1 & PC2 & PC3 \\
\hline $\mathbf{5 0 \% T}$ & 0.031 & 27.634 & 0.089 \\
\hline $\mathbf{5 0 \% S}$ & 0.007 & 28.194 & 1.012 \\
\hline PH & 2.683 & 2.809 & 35.835 \\
\hline EH & 6.368 & 0.782 & 26.700 \\
\hline LODG & 0.622 & 13.384 & 9.691 \\
\hline FW & 21.284 & 0.449 & 4.537 \\
\hline GM & 3.029 & 15.007 & 1.089 \\
\hline EA & 28.254 & 0.148 & 1.404 \\
\hline T & 7.880 & 1.700 & 9.107 \\
\hline RE & 1.588 & 9.744 & 9.134 \\
\hline PA & 28.254 & 0.148 & 1.404 \\
\hline
\end{tabular}

Where $50 \% \mathrm{~T}=50 \%$ tasseling, $50 \% \mathrm{~S}=50 \%$ silking, $\mathrm{PH}=$ plant height, $\mathrm{EH}$ = ear height, $\mathrm{LODG}=$ srem lodging, $\mathrm{FW}=$ field weight, $\mathrm{GM}=$ grain moisture, $\mathrm{EA}=$ ear aspect, $\mathrm{T}=$ ear texture, $\mathrm{RE}=$ rotten ear, $\mathrm{PA}=$ plant aspect.

Contribution of PC1 towards variability was highest (29.37\%) followed by PC2 and PC3 which contributed $26.52 \%$ and $14.29 \%$ variability respectively (Table 7). In PC1 and PC2 together 50\% silking, 50\% tasseling, plant height, ear height, ear aspect, plant aspect, field weight, rotten ear, ear texture and grain moisture's differences are well represented in the biplot showed that all trait. In summary, results of PCA analysis showed that all traits contribute differently in total variation. These variations are sources of germplasm improvement in the respective quantitative trait which contribute toward better agronomic performance and increase in yield potential. In biplot graph it was clearly indicated that there plant height and ear height had strong positive correlation among them (Figure 8).

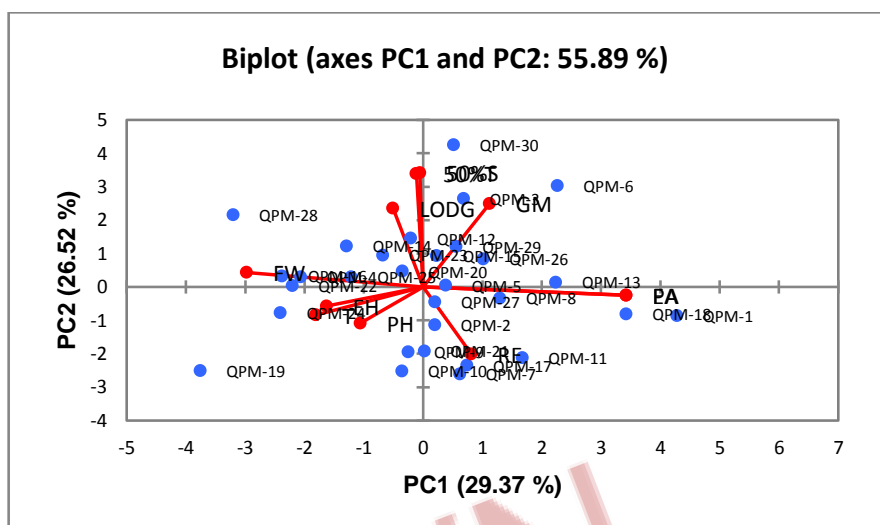

Figure 8: Two dimensional orientations of maize QPM hybrids for different traits on principle component biplot axis 1 and 2 . Where $50 \% \mathrm{~S}=$ days to $50 \%$ silking, $50 \% \mathrm{~T}$ = days to $50 \%$ tasseling, $\mathrm{PH}=$ plant height, $\mathrm{EH}$ $=$ cob height, $\mathrm{T}=$ texture, $\mathrm{PA}=$ plant aspect, $\mathrm{EA}=$ ear aspect, $\mathrm{GM}=$ grain moisture, $\mathrm{RE}=$ rotten ears and $\mathrm{LODG}=$ stem lodging.

A principal component scatter plot of maize germplasm depicts those genotypes which are similar in their performance with respect to eleven variables. Whereas genotypes which are father apart from one another are different. Genotypes which are more near to variable vectors are more important for that trait and vice versa. Therefore scatter plot helped in the selection of genotypes for the yield contributing trait or for the trait that helped in better agronomic performance. In a given biplot it as clearly indicated that QPM hybrids QPM 25, QPM 16, QPM 4 and QPM 24 are more important for field weight parameter. QPM 11, QPM 17, 7, 10 and 21 had more rotten ears among thirty hybrids. QPM hybrids 30 and 3 are more important for flowering parameters. QPM 18, 1 and 13 had better ear aspect (Figure 8).

In case of QPM hybrids cluster and principal component analysis of genotypes and trait showed the maize germplasm investigated has tremendous genetic diversity which may be of a great potential source for the future maize breeding strategies. Different quantitative traits preferably plant height, ear height, field weight, grain moisture, plant lodging and grain moisture contents or the combination of few or more can be useful for breeding programs. The dendrogram grouped all genotypes on the basis of their similarity into three clusters, A, B and C for both QPM and inbred lines. Sood also performed PCA and cluster analysis on 40 QPM and non QPM lines that generate seven clusters on the base of various flowering and yield traits [16]. Both PCA and cluster analysis showed clearly differences between QPM and non QPM lines. Groups that were formed by PCA and cluster in the present study can be exploit for breeding purposes for enhancing quality in maize grain.

\subsection{Cluster analysis}

According to a group researcher cluster analysis has significant ability to recognize the synonymies and homonymous accessions at different degree of similarities in the form of dendogram [39-44].

All 50 maize genotypes were grouped into three clusters A, B and C based on 13 agro-morphological traits (Figure 7). Cluster A consisted of 30 genotypes that were found to had lower values of plant height (148.78 \pm 21.28$)$, ear height $(65.19 \pm 17.45)$, ear diameter $(36.08 \pm 5.46)$, yield per plant $(52.12 \pm 23.04), 100$ grain weight $(25.78 \pm 5.94)$. Cluster B which is characterized by having similar performance in the agromorphological traits between 15 genotypes. These traits include highest value for plant height $(184.501 \pm 21.28)$, highest value for ear height 
(88.253 \pm 17.45$)$, highest value for number of ears $(1.322 \pm 0.23)$, highest value for number of rows per ear $(14.11 \pm 1.98)$, maximum days to complete $50 \%$ tasseling $(39 \pm 6.18)$, maximum days to complete $50 \%$ silking (51 \pm 7.38$)$ and more days interval between anthesis and silking $(12 \pm 4.19)$. Cluster C was found to have five genotypes having similar performance of having maximum ear length $(14.45 \pm 2.44)$, maximum value for yield per plant $(111 \pm 23.04)$, maximum value for 100 grain weight (30.71 \pm 5.94$)$ and maximum number of grains per row (35.83 \pm 7.47$)$.

Cluster analysis grouped 30 maize QPM hybrids into three groups A, B and $C$ having similar performance in agro-morphological traits (Figure 8) [4548]. Cluster A consisted of 13 genotypes that had characteristics features of having highest days to complete $50 \%$ tasseling ( $48 \pm 2.18$ ), highest days to complete $50 \%$ silking $(50 \pm 2.17)$, least value for plant height (198.59 \pm 16.66$)$, least value for ear height (106.86 \pm 10.83$)$, maximum grain moisture contents $(33.46 \pm 2.81)$, maximum value for ear aspect $(3.00 \pm 0.51)$ and maximum numbers of rotten ears $(1 \pm 1.09)$. Cluster B comprised of 14 hybrids that had prominent features of similar performance like maximum ear height $(122.93 \pm 10.83)$, minimum grain moisture contents $(31.01 \pm 2.81)$. Cluster $\mathrm{C}$ was found tohad three hybrids with similar agro-morphological traits like minimum days to complete $50 \%$ tasseling (46 \pm 2.18$)$, minimum days to complete $50 \%$ silking (47 \pm 2.71$)$, maximum plant height $(241.87 \pm 16.66)$ and maximum numbers of lodged plants $(4.33 \pm 2.96)$.

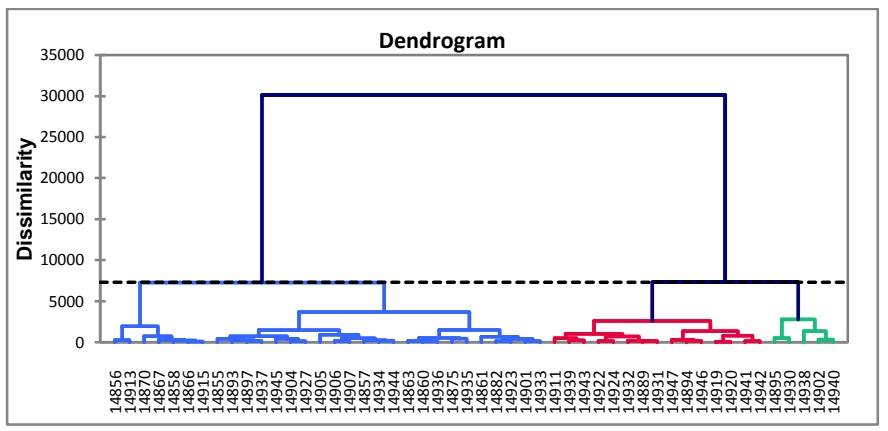

Figure 9: Cluster analysis of 50 maize inbred lines

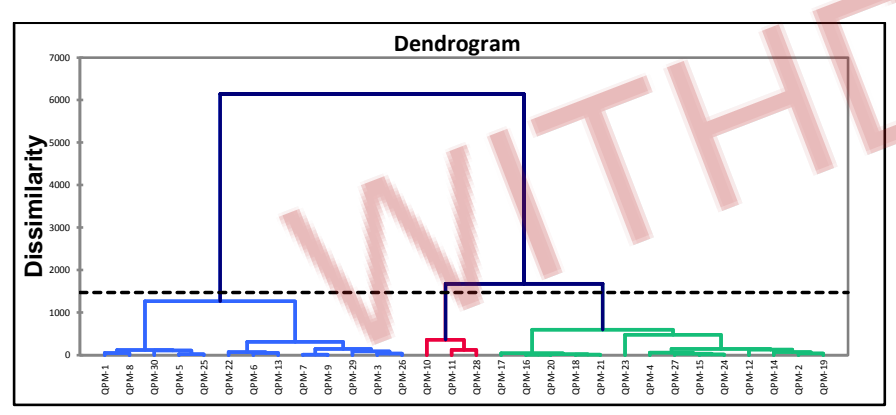

Figure 10: Cluster analysis of 30 QPM hybrids

\section{CONCLUSIONS}

As there was no opaque 2 gene in 50 genotypes therefore for the breeding of maize genotypes with high level of tryptophan, opaque 2, opaque 7 and floury 2 genes should be incorporated by introducing QPM lines from CIMMYT for quality protein bio-fortification to alleviate protein malnutrition. Correlation plays pivotal role in the selection of right traits for breeding purposes. Different quantitative traits preferably plant height, ear height, field weight, grain moisture, plant lodging and grain moisture contents or the combination of few or more can be useful for breeding programs. The identification of high level of genetic diversity during the current study could be used for maize germplasm characterization, conservation and further improvement in maize breeding.

\section{REFERENCE}

[1] FAO, IFAD and WFP. 2015. The State of Food Insecurity in the World 2015. Meeting the 2015 international hunger targets: taking stock of uneven progress. Rome, FAO.

[2] Ranum, P., Peña-Rosas, J.P., Garcia-Casal, N.M. 2014. Global maize production, utilization, and consumption. Annals of the New York Academy of Sciences, 1312 (1), 105-112.

[3] Gibbon, B.C., Larkin, B.A. 2005. Molecular genetic approaches to developing quality protein maize. Trends Genet, 21, 227-233.
[4] Young, V.R., Scrimshaw, N.S., Pellet, P.L. 1998. Significance of dietary protein source in human nutrition: animal and/or plant proteins? pp 205-221. In: J. C. Waterlow, D. G. Armstrong, L. Fowden, and R. Riley (eds), Feeding a World Population of more than Eight Billion People. Oxford University Press in associate with Rank Prize Funds, New York.

[5] Vivek, B.S., Krivanek, A.F., Palacios-Rojas, N., Twumasi-Afriyie, S., Diallo. A.O. 2008. Breeding quality protein maize (QPM): Protocols for developing QPM cultivars. CIMMYT.

[6] Paroda, R., Prasanna, B.M., Mal, B., Dasgupta, S., Jat, M.L. 2015. Maize for food, feed, nutrition and environmental Security. Proc. 12th Int. Maize conf., 300ct-1Nov, Bangkok, Thailand.

[7] Soave, C., Suman, N., Viotti, A., Salamini, F. 1978. Linkage relationships between regulatory and structural gene loci involved in zein synthesis in maize. Theoretical and Applied Genetics, 52 (6), 263-267.

[8] Kodrzycki, R., Boston, R.S., Larkins, B.A. 1989. The opaque-2 mutation of maize differentially reduces zein gene transcription. The Plant Cell, 1 (1), 105-114.

[9] Munck, L. 1992. The case of high-lysine barley breeding. pp 573-601. In: Shewry (ed), Barley, Genetics, Biochemistry, Molecular Biology and Biotechnology, CAB International, Wallingford.

[10] Olakojo, S.A., Omueti, O., Ajomale, K., Ogunbodede, B.A. 2007. Development of quality protein maize: biochemical and agronomic evaluation [desarrollo de maíz qpm: evaluación bioquímica y agronómica]. Tropical and Subtropical Agroecosystems, 7, 97-104.

[11] Crow, J.F., Kermicle, J. 2002. Oliver Nelson and quality protein maize. Genet, 160 (3), 819-821.

[12] Gunaratna, N.S., Groote, H.D., Nestel, P., Pixley, K.V., McCabe, G.P. 2010. A meta-analysis of community-based studies on quality protein maize. Food policy, 35 (3), 202-210.

[13] Jacobs, D.R., Meyer, K.A., Kushi, L.H., Folsom, A.R. 1998. Whole-grain intake may reduce the risk of ischemic heart disease death in postmenopausal women: the Iowa Women's Health Study. American Journal of Clinical Medicine Research, 68, 218-219.

[14] Saiki, R.K., Gelfand, D.H., Stoffel, S., Scharf, S., Higuchi, R., Horn, G.T., Mullis, K.B., Erlich, H.A. 1988. Primer directed-enzymatic amplification of DNA with a thermostable DNA polymerase. Science, 239, 487-491.

[15] Beckmann, J.S., Soller, M. 1990. Toward a unified approach to geneticmapping of eukeryote based on sequence tagged microsatellite sites. Biotechnol, 8, 930-932.

[16] Sood, A., Thakur, K., Sharma, P.N., Gupta, D., Singode, A., Rana, M., Lata, S. 2017. A Comprehensive Study of Variation in Selected QPM and NonQPM Maize Inbred Lines. Agricultural Research, 1-11.

[17] Steel, R.D.G., Torrie, J.H., Dickey, D.A. 1997. Principles and Procedures of Statistics: A Biometrical Approach, (3rd ed.) McGraw Hill Book Co., New York. USA.

[18] Rencher, A.C. 1995. Methods of multivariate analysis: Cluster analysis, (2nd ed.). John Willy and Sons inc. USA.

[19] Weinstein, J. 2008. A post genomic visual icon. Science, 319, 17721773.

[20] Babu, R., Nair, S.K., Kumar, A., Vekantesh, S., Sekhar, J.C., Singh, N.N., Srinivasan, G., Gupta, H.S. 2005. Two-generation marker aided backcrossing for rapid conversion of normal maize lines to quality protein maize (QPM). Theoretical and Applied Genetics, 111, 888-897.

[21] Ghimire, B., Timsina, D. 2015. Analysis of yield and yield attributing traits of maize genotypes in Chitwan, Nepal. World Journal of Agricultural Research, 3 (5), 153-162.

[22] Dijak, M., Modarres, A.M., Hamilton, R.I., Dwyer, L.M., Stewart, D.W., Mather, D.E., Smith, D.L. 1999. Leafy reduced-stature maize hybrids for short-season environments. Crop Science, 39 (4), 1106-1110.

[23] Ihsan, H., Khalil, I.H., Rahman, H., Iqbal, M. 2005. Genotypic variability for morphological and reproductive traits among exotic maize hybrids. Sarhad Journal of Agriculture, 21, 599-602. 
[24] Shrestha, J. 2013. Agro-morphological characterization of maize inbred lines. Sky Journal of Agricultural Research, 2 (6), 85-87.

[25] Yucel, C., Hizli, H., Firincioglu, H.K., Cil, A., Anlarsal, A.E. 2009. Forage yield stability of common vetch (Vicia sativa L.) genotypes in the Cukurova and GAP Regions of Turkey. Turkish Journal of Agriculture, 33 (2), 119125.

[26] Golam, F., Farhana, N., Zain, M.F., Majid, N.A., Rahman, M.M., Rahman, M.M., Kadir, M.A. 2011. Grain yield and associated traits of maize (Zea mays L.) genotypes in Malaysian tropical environment. African Journal of Agricultural Research, 6 (28), 6147-6154.

[27] Singha, N., Prodhan, S.H. 2000. Character association in green maize. Env. Eco., 18, 962-5.

[28] Najeeb, S., Rather, A.G., Parray, G.A., Sheikh, F.A., Razvi, S.M. 2009. Studies on genetic variability, genotypic correlations and path coefficient analysis in maize under high altitude temperate ecology of Kashmir. MNL, 46.

[29] Bocanski, J., Sreckov, Z., Nastasic, A. 2009. Genetic and phenotypic relationship between grain yield and components of grain yield of maize (Zea mays L.). Genetika, 41 (2), 145-154.

[30] Iqbal, J., Shinwari, Z.K., Rabbani, M.A. 2015. Maize (zea mays l.) Germplasm agro-morphological characterization based on descriptive, cluster and principal component analysis. Pakistan Journal of Botany, 47, 255-264.

[31] Malik, H.N., Malik, S.I., Hussain, M.O.Z.A.M.I.L., Chughtai, S.U.R., Javed, H.I. 2005. Genetic correlation among various quantitative characters in maize (Zea mays L.) hybrids. Journal of Agriculture, Forestry and the Social Sciences, 3, 262-265

[32] Chase, S.S., Nanda, D.K. 1967. Number of leaves and maturity classification in Zea mays L. Crop Science, 7, 431-3.

[33] Edmeades, G.O. 1996. Developing Drought and Low N-tolerant Maize: Proceedings of a Symposium, March 25-29, CIMMYT, El Batan, Mexico. CIMMYT.

[34] Tandzi, N.L., Ngonkeu, E.L.M., Youmbi, E., Nartey, E., Yeboah, M., Gracen, V., Mafouasson, H.A. 2015. Agronomic performance of maze hybrids under acid and control soil conditions. IJAAR, 6 (4), 275-291.

[35] Akbar, M., Shakoor, M.S., Husein, A., Sarwar, M. 2008. Evolution of maize 3-way crosses through genetic variability, broad sense heritability, characters association and path analysis. Journal of agricultural research, 46 (1), 39-45.

[36] Sabaghnia, N., Dehghani, H., Alizadeh, B., Moghaddam, M. 2011. Yield analysis of rapeseed (Brassica napus L.) under water-stress conditions using GGE biplot methodology. Journal of Crop Improvement, 25 (1), 2645.

[37] Alvi, M.B., Rafique, M., Tariq, M.S., Hussain, A., Mahmood, T., Sarwar M. 2003. Character association and path coefficient analysis of grain yield and yield components maize (Zea mays L.). Pakistan Journal of Biological Sciences, 6 (2), 136-138.

[38] Yan, W., Tinker, N.A. 2005. An integrated system of biplot analysis for displaying, interpreting and exploring genotype by-environment interactions. Crop Science, 45, 1004-1016.

DOI:10.2135/cropsci2004.0076.

[39] Aliyu, B., Ng, N.Q., Fawole, I. 2000. Inheritance of pubescences in crosses between Cowpea (Vigna unquiculata (L)) WAIP) and V. Rhomboidea Burtt. Davy.

[40] Bantte, K., Prasanna, B.M. 2003. Simple sequence repeat polymorphism in Quality Protein maize (QPM) lines. Euphytica, 129, 337344 .

[41] Bender, D.A., Bender, A.E. 1999. Benders' Dictionary of Nutrition and Food Technology (7th ed.). Woodhead Publishing. Abington.

[42] Danson, J.W., Mbogari, M., Kimani, M., Lagat, M., Kuria, A., Diallo, A. 2006. Marker assisted introgression of opaque-2 gene into herbicide resistant elite maize inbred lines. African Journal of Biotechnology, 5 (24), 2417-2422.

[43] FAO. 2002. World Agriculture: Towards 2015/2030. Summary Report. FAO, Rome.

[44] FAO. 2014. The state of food insecurity in the world 2014, FAO.

[45] Gupta, P.K., Varshney, R.K., Sharma, P.C., Ramesh, B. 1999. Molecular markers and their applications in wheat breeding. Plant Breed, 118 (5), 369-390.

[46] Lopez, M.A., Gloverson, L., Larkins, B. 2004. Genetic mapping of opaque2 modifier genes. Maize Genetics Cooperation Newsletter, 69, 165.

[47] Prasanna, B.M., Vasal, S.K., Kassahun, B., Singh, N.N. 2001. Quality protein maize.

[48] Shanker, A.K., Cervantes, C., Loza-Tavera, H., Ayudainayagam, S. 2005. Chromium toxiticity in plants. Environment International, 31, 739-753.

[49] Yan, W., Rajcan, I. 2002. Biplot analysis of test sites and trait relations of soybean in Ontario. Crop Sci., 42, 11-20.

http://crop.scijournals.org/cgi/content/abstract/42/1/11. 